\title{
CORONA VIRUS PANDEMIC AND THE CHANGING NATURE OF INTERNATIONAL RELATIONS
}

\author{
Chris S. Orngu, $\mathrm{PhD}^{1}$ and Adeyemi Adesola ${ }^{2}$ \\ ${ }^{1}$ Department of History, Benue State University, Makurdi, Nigeria \\ ${ }^{2}$ Department of International Relations, Ecole Superieure Panafricaine de Management Applique \\ (Pan African University), Cotonou, Benin Republic
}

DOI: 10.46609/IJSSER.2020.v05i12.009 URL: https://doi.org/10.46609/IJSSER.2020.v05i12.009

\begin{abstract}
Since the emergence of the modern state system in 1648, the nature of relations among nationstates in the international system has steadily witnessed a noticeably unending dynamism. The unending dynamism of inter-state relations is essentially a function of a multiplicity of historical factors and the ever-changing nature of the international system. Major wars, advances in science and technology, the revolutionary trends in Information and Communications Technology (ICT), international terrorism, the forces of globalization and economic internationalism are some of the important historical factors that are known to have driven the trends and dimensions of inter-state relations over time. The corona virus pandemic is the latest global phenomenon that appears to have influenced the nature of international relations in contemporary times. This paper is concerned with the extent to which the outbreak of the corona virus pandemic has altered the nature of international relations. The paper adopts a multidisciplinary methodology to interrogate the relevant issues. Preliminary investigations reveal that the pandemic demonstrates one of the downsides of globalization. It argues that the corona virus pandemic has a telling impact on the nature of international relations in more negative ways now and in the unforeseeable future. It concludes that international relations will always come under the influence of global dynamics. The paper suggests that a global synergy in the area of proactive approaches through advances in medical science is required to prevent the reoccurrence of a similar global pandemic.
\end{abstract}

Keywords: corona virus pandemic, diseases, international relations, globalization

\section{Introduction}

The World War I and World War II significantly transformed the nature of inter-state relations with the formation of multilateral public institutions - the League of Nations and the United Nations - through which nations came under common platforms to pursue collective security in 


\section{International Journal of Social Science and Economic Research}

ISSN: $2455-8834$

Volume:05, Issue:12 "December 2020"

the interest of international peace and security. The League and the UN encouraged multilateralism and conference diplomacy through which nations of the global system began to vigorously interact on a common platform with definite grand norms to pursue collective interests. The Great Depression of 1929 with its concomitant catastrophic effects on food supply and socio-economic aspects of humanity altered the parameters of the global economy and transformed the nature of international economic relations. The experience of the depression inspired the need for a comprehensive review of international relations frameworks by focusing on global environmental cooperation to address future risks that the world may face as a result of increased carbon dioxide emissions and its destructive impact on the financial environment. The Cold War era created a bipolar world order that influenced the trends and dimensions of power politics in the $20^{\text {th }}$ century international relations. The Cold War instigated a high profile ideological hostility with its attendant uncertainties and fears that encouraged the formation of alliances, the arms race and a seemingly unending struggle for power among nations. The unintended consequences of the Cold War and other related developments in the world system have manifested a deep-seated disparity problematic, which has become a defining characteristic of international relations in the $20^{\text {th }}$ and $21^{\text {st }}$ centuries.

Amidst the disparity problematic in the international system are escalating international security challenges, global economic crises, trans-border conflicts, power politics and the struggle for power among nations and the endless acquisition of military arsenals with unimaginable destructive capabilities. All these are obvious threats to the survivability of humanity and destabilizing factors that confront the essence of international relations. Beyond this litany of threats to the essence of international relations, there is the challenge of global health that is thrown up by the globalization of diseases.

Beginning from the last century, the global system has come under the yoke of a number of pandemics that have threatened the survivability of mankind. The dreaded HIV/AIDS pandemic is a vivid illustration of how globalization has provided an amenity for the spread of diseases at a global scale. Invariably, this illustration demonstrates how international relations can be affected by a global pandemic.

The emergence of the corona virus disease in China in December 2019 and its subsequent spread across the entire globe has elicited serious attention from the nooks and crannies of the international system. The magnitude of the horrifying images, the increasing quantum of death tolls occasioned by the pandemic and the challenge that it has placed before the global health system are indicators that the international system has come face to face with a new set of dynamism. The business of this intellectual engagement is to interrogate and bring out the extent to which the novel health challenge - corona virus pandemic - has altered the nature of contemporary international relations now and in the unforeseeable future. 
International Journal of Social Science and Economic Research

ISSN: 2455-8834

Volume:05, Issue:12 "December 2020"

\section{International Relations: A Conceptual and Theoretical Exploration}

Defining International Relations can be intellectually tasking and conceptually conflicting. More often than not, international relations is perceived as an abstract and distant ritual that is conducted by a special and small group of people such as presidents and diplomats alone (Robert J. Art \& Robert Jervis, 1996; Joseph S. Goldstein, 2004). There is also the confusion between international relations as a separate academic discipline and international relations as an art. While the former deals with the subject matter and science of inter-state relations and international politics, the latter dwells essentially on the environment and conduct of trans-border relations. A deliberate effort is, therefore, made here to explore the meaning of international relations in a manner that ambiguity is extenuated. Thus, the conceptual domain of international relations is consciously tailored to reflect a common sense understanding of the concept within the mental construct of this discussion.

Simplistically, international relations may be explained to mean any interaction that transcends national borders. Such interactions may take place between both state actors and non-state actors in the pursuit of self-seeking interests. In a narrow technical sense, it means the interactions and relationships among the world's governments (Joshua S. Goldstein \& Jon C. Pevehouse, 2011:3). This definition is narrow in context especially given that international relations may sometimes involve a multiplicity of actors completely outside of sovereign states and their governments. To some extent, the validity of this definition is restricted to state-centric perspective of international relations, where state actors or national governments are considered as the dominant and most important actors in world affairs. To that extent, Goldstein and Pevehouse further elaborate that the relationships among world's governments cannot be understood in isolation since they are connected with other actors such as multilateral institutions, multinational corporations and individuals (Goldstein \& Pevehouse, 2011:3). Apart from multilateral institutions, multinational corporations and individuals, there are other important actors like terrorist groups that operate and interact at global scale and are considered to be important actors in international relations. Thus, all the key elements identified here are very important players in international relations as they relate and interact in the pursuit of varying and self-seeking goals.

According to Chris Brown (2005:1) international relations can correctly mean the diplomaticstrategic relations of states with a strategic focus on issues of war and peace, conflict and cooperation. Added to that, Brown (2005:5) further argues that international relations refer to cross-border transaction of all kinds covering important areas within the political, economic, and socio-cultural domains. The whole set of these interactions is facilitated by a number of factors which include globalization, transportation, information and communications technology. It is on the basis of this realization that one can plausibly argue that globalization has significantly influenced the nature and patterns of international relations in the later part of the $20^{\text {th }}$ century 


\section{International Journal of Social Science and Economic Research}

ISSN: $2455-8834$

Volume:05, Issue:12 "December 2020"

and now more tangibly in the $21^{\text {st }}$ century. Thus, the globalization of international relations simply implies the broadening of the frontiers of international relations through the facility and instrumentality of globalism.

A proper understanding of the operational tenet of international relations is achievable when anchored on a proper theoretical foundation. Many theories have been advanced to underpin the analytical contents and contexts of international relations. Most of these theories are embedded with conflicting perspectives among themselves in terms of their intellectual premises. In this discussion, attention is given to the international relations theory of pluralism and complex interdependence. The theory is essentially a departure from other contending theories of international relations and its relevance is explored to drive the logic of our argument in this discussion. There is no doubt that the realist argument of international relations enjoys some measure of popularity among many scholars. However, the choice of this theoretical exploration is deliberately intended to achieve some measure of explanatory powers on international relations outside the popular domain of realism since the preferred theory has the intellectual ingredients needed to sufficiently bring out the theoretical prepositions that will guide the analytical thrust of the work.

During the $20^{\text {th }}$ century, precisely, in the mid-1970s, pluralism appeared to be in the process of firmly establishing itself as a dominant alternative theory of international relations. As a departure from the realist tradition, pluralism had decidedly preserved some of the penetrating insights of realism; for instance, about the importance of power, while at the same time offering a far more complex and nuanced account on how these insights might be operationalized in the analysis of international relations (Brown, 2005:17). Basic to the theoretical assumption of pluralism is the notion that the world system is mutually interdependent, linking the rich and the poor in a complex web of interdependence. Thus, the theory of pluralism and complex interdependence presents a portrait of global order with an organic composition of many interdependent components represented as state and non-state actors who are constantly relating and interacting in the pursuit of their mutually defined interests. Furthermore, the theory assumes, and correctly, too, that there are multiple channels of interaction between societies, including different branches of the state apparatuses as well as state and non-state actors as opposed to the Unitarian assumption of the realist intellectual tradition. Thus, the assumption of pluralism and complex interdependence is that, for most international interactions, the use of force will assume a lower order and there is no hierarchy of issues on international agenda. Whereas the realist tradition insists that issues of war and security should constantly occupy the highest order on international agenda, the pluralist and complex interdependence tradition believes that preferences and priority issues on international agenda are defined by prevailing circumstances. 


\section{International Journal of Social Science and Economic Research}

ISSN: $2455-8834$

Volume:05, Issue:12 "December 2020"

The assumption of the pluralist and complex interdependence tradition that priority issues on international agenda should emerge from prevailing circumstances has a plausible measure of relevance in explaining the relationship between the outbreak of the novel corona virus pandemic and the spontaneous reactions of state and non-state actors in the international system. It is obvious that the outbreak of the pandemic and the concerted efforts by international actors to deal with its associated emergent challenges instantaneously took the highest order in the hierarchy of issues on the international agenda and momentarily eclipsed other burning issues of concern in the international system. To that extent, the outbreak of the corona virus pandemic and the changing nature of international relations can be appropriately explained and adequately understood within the framework of the theory of pluralism and complex interdependence.

\section{International Relations and the Globalization of Diseases}

Arguably, international relations and globalization are two sides of the same coin. The first side of the coin symbolizes a global community of complex interdependence while the second side of the coin symbolizes the fizzling of geographical barriers and the shrinking of distances in the global community to create a pluralist and complex global neighborhood. The globalization of international relations has a number of both advantages and disadvantages (Robert D. Kaplan, 2000). In this discussion, one major disadvantage, which is the spread of diseases through the facility and instrumentality of globalization, is the main concern. The spread of diseases across human societies is not a new phenomenon in world history. As human societies began to grow and expand their interactions, the spread of diseases across wide geographical scales began to increase through history. The globalization of diseases may have commenced during the exploration age between the $15^{\text {th }}$ and $17^{\text {th }}$ centuries when European explorers ventured into the discoveries of new territories of human habitations and the subsequent drive of European powers to acquire and control territories outside of Europe for various reasons. In the time past, diseases like bubonic plague, influenza and a few other infectious diseases had spread from Asia to Europe through contacts between peoples of the two continents (N. Daulaire, 1999). With time, however, the increasing contacts between human societies across continents expanded the scope and dimensions of the spread of infectious diseases in the world system.

Given the current waves of globalization and transnational interactions, the world has become interdependent and interlaced more than ever before. With efficient and accessible transportation systems and increasing global trade in products and services, more people are increasingly coming into contact. The availability of accessible transport systems facilitates local and transnational contacts, encourages international migration and promotes cross-border tourist activities. International trade in products and services - an important component of economic globalization - also constantly brings people into physical contacts. International trade in agriculture is known to have brought people into contact with animal diseases that have 


\section{International Journal of Social Science and Economic Research}

ISSN: $2455-8834$

Volume:05, Issue:12 "December 2020"

subsequently jumped species barriers. Some of the diseases that have gained global penetration in recent time on the behest of the current of globalization and international relations are HIV/AIDS, Ebola and, most recently, Corona Virus Disease.

HIV/AIDS: this is known as the Human Immuno-Deficiency Virus/Acquired Immune Deficiency Syndrome. It ranks very high among the deadliest global diseases. Before the advent of the corona virus disease, it was the deadliest with the stature of an apocalypse. Beyond speculations, there are no clearly substantiated scientific claims regarding the origin of the disease. According to the World Health Organization and other researches, the HIV virus appeared to have moved from animals to humans (Chris S. Orngu, 2007: 20-21). The first two AIDS/HIV cases were detected in the 1980s (Orngu, 2007: 22). Since then, its spread across the globe had remained unprecedented both in speed and magnitude until the emergence of the corona virus disease. According to a WHO report, by 2013, an estimated 1.3 million persons in the United States were living with HIV/AIDS, almost 110,000 in the UK and an estimated 35 million people worldwide were living with HIV (http:www.who.int/hiv/data/epi_core_dec20.14).

There have been concerted efforts in many countries, global awareness/sensitization campaigns and prevention programmes to check the growing spread of HIV/AIDS at local and international scales; but it appears that these efforts have not been effective enough to reduce the numbers of new HIV cases in many parts of the world. This reality is associated with high mobility of humans with indulgence in sexuality among certain populations and transnational interactions.

Ebola Virus Disease(EVD): the Ebola Virus Disease outbreak started in Guinea in March 2014 and spread across a number of African countries within a short period of time. On July 20, 2014, the first EVD was detected in Nigeria and was reported to have been brought into the country by a Liberian who flew into Lagos by aeroplane. The man died in the hospital five days later - an incident that set off a chain of transmission that infected a total of nineteen persons within a short time with seven deaths recorded (www.who.int.news. Retrieved 10/09/2020). The WHO warned that the number of Ebola cases could rise to 20,000 within the continent with attendant cost implications within six to nine months (The Guardian, August 28, 2014). This prediction was based on the astronomical rise in the number of reported cases that had spread across the continent within a short time of the outbreak.

The experience with the outbreak and subsequent spread of the EVD also expresses a core danger embedded in trans-border human mobility and interactions in a globalized world. The fact that the outbreak of the disease was recorded in Guinea in March 2014, and in three months time, it had crept into Nigeria through Liberia, and had been reportedly detected in Central Africa, Sierra Leone and other parts of the continent clearly demonstrates how fast diseases travel in the era of globalization and trans-border interactions. 


\section{International Journal of Social Science and Economic Research}

ISSN: $2455-8834$

Volume:05, Issue:12 "December 2020"

Corona Virus Pandemic: The Corona Virus Disease originated and was first detected in Wuhan, China in December 2019; which is why it is commonly called Covid-19 (Corona Virus Disease 2019). The outbreak of the disease has since caused a challenging health issue in China and has swiftly snowballed into a catastrophic global health challenge which the World Health Organization has since March 11, 2020, declared a global pandemic (WHO, 2020).

By May 2020, medics and other health scientists had convincingly linked the corona virus, a zoonotic disease, to the wet markets in China (www.idtechex.com. Retrieved 10/09/2020). As more people continuously travelled and more goods and capital traded globally, Covid-19 cases gradually and steadily began to appear all over the world. By early June 2020, the number of confirmed Covid-19 cases around the globe stood at 8.5 million with confirmed death cases related to the pandemic hitting 460,000 globally and 4.5 million recovered cases (www.worldmeters.info. Retrieved 10/09/2020). As it stands now, the United States has outdistanced other countries with almost 2.26 million confirmed cases of the corona virus disease with a death toll that has crossed 120,000 - the highest death count in any other country in the world so far (www.worldmeters.info. Retrieved 10/09/2020). The first ever confirmed case of Covid-19 in the United States was in Washington on January 21, 2020 (www.aljazeera.com. Retrieved 10/09/2020). Curiously, this was traced to a man who had just returned to Washington from China. Since then, the United States has been locked in the desperate efforts of containing the spread of the disease with little successes as evident in the growing number of confirmed cases in the country. Trailing behind the United States are Brazil, Russia, Spain, the United Kingdom and Italy which are known to have all suffered steady increases in the number of Covid-19 confirmed cases leading to the crippling of their health systems and economic disequilibria. Nigeria and other African countries have equally been trapped in the devastating experience of Covid-19 with its attendant consequences.

There is no doubt that Covid-19 is the newest and deadliest global pandemic that has spread so fast across the globe within a short period of time more than any other global or continental pandemic known in history so far. This is explainable. The sophistication and complexity of globalism and transnational encounters in contemporary international relations are unprecedented. It is, therefore, expected that communicable or infectious diseases will travel faster and wider in this age of globalization with human beings inadvertently becoming carriers and transmitters of such diseases across national borders.

\section{Corona Virus Pandemic and International Relations: An Impact Analysis}

The outbreak and subsequent spread of corona virus disease has had a telling impact on international relations in a variety of ways. To begin with, the fear that has gripped the international system as a result of the outbreak and spread of Covid-19 is strong enough to alter 


\section{International Journal of Social Science and Economic Research}

ISSN: $2455-8834$

Volume:05, Issue:12 "December 2020"

the parameters of international relations. For instance, following the first confirmed case of Covid-19 in the United States in Washington January 21, 2020, President Donald Trump of the United States announced the restriction on travels to and from China with effect from February 2, 2020 (www.aljazeera.com. Retrieved 10/09/2020). Similarly, on March 11, 2020, Trump issued an executive order to restrict travels from Europe, except for the UK and Ireland (www.aljazeera.com. Retrieved 10/09/2020); and on May 24, 2020, Trump banned travels from Brazil when the country became the new epicenter of the corona virus pandemic (Andrea Salcedo, Sanan Yar \& Gina Cherelus, 2020). On March 19, 2020, the State Department of the US marked some countries as Level 4 into which US citizens were restrained from visiting (Andrea Salcedo, Sanan Yar \& Gina Cherelus, 2020). Almost all countries followed the trend of travel restrictions and, by May, 2020, it was obvious that trans-border travels had become severely restricted with the shutting down of international airports in the entire global system. This development ultimately grounded a great measure of international diplomacy and international economic relations.

The import of these restrictions on trans-border travels was to curtail the latitude of free entry by international entities into countries other than their own in order that the potentials for carrying and spreading the virus could be checked. Apparently, national governments understood that through the accessibility in travel and free trade, any local or international traveler could be a potential carrier of the virus to a new environment. In the main, the corona virus pandemic travel restrictions have so far affected a significant percentage of the global population and the trends of international relations in a variety of ways.

Again, it has become clear and understandable too that the repercussions of the corona virus disease have cast a shadow on the relations within the European Union - a situation that is increasingly becoming threatening to the future of EU and which has strengthened the growth of the power of the right-wing populist currents. In the event that this trend goes unabated, it will garner the proclivity to enhance the politics of self-sufficiency and isolation, which will likely lead to the destabilization of the EU and its institutions in the long run. The experience of Austria, Germany, Italy, Portugal, and Spain is sufficient to drive home this point.

The good news is that there is a positive side to which the corona virus pandemic can be dimensioned in the nature of international relations. On the positive side, the Corona virus crisis has shifted international actors towards cooperation more than competition and conflict that have always been the dominant characteristics of international relations. Obviously, the areas of cooperation between the United States, China and Russia in managing the consequences and preventing the further spread of the corona virus pandemic within the frameworks of information and experience exchanges and mutual medical assistance have expanded significantly in the wake of an era that the conspiracy theory reemerged in driving the blame game of which party 


\section{International Journal of Social Science and Economic Research}

ISSN: $2455-8834$

Volume:05, Issue:12 "December 2020"

that was a source of the spread of the virus and syndicated counter-accusations. In fact, it was the concerted efforts of major international actors that drove the information dissemination mechanism that helped so much in creating the global awareness on the true existence of the corona virus disease and its associated horrifying consequences for humanity.

\section{International Relations in Post-Corona Pandemic Era}

The future of international relations in the post-corona pandemic era presents a crystal ball of predictable and unpredictable variables. Deriving from the ongoing currents in the international system against the backdrop of corona virus pandemic, it is tempting to argue that the contours of international relations are under siege. For sure, the concerted efforts of international actors will eventually humble the pandemic and whittle down its tentacles. In the worst of situations, the international community will learn to live with the pandemic in the same way as HIV/AIDS.

The post-corona era will strengthen cooperation among the powerful nations of the global system more than ever before. Their collective strength will be explored to widen the gulf between the stronger and weaker nations for sustained exploitation and hegemonic offensive. The superiority of the stronger countries, which is already manifesting in their efforts towards breakthroughs in medical science and the international politics that belies the search for the vaccine against the corona virus disease are already setting the stage for lopsided international relations in a postcorona pandemic era.

The post-corona pandemic era is set to deepen the disparity between the rich and poor countries of the global system. The global economy has been dislocated by the effects of the corona virus disease. It is easier for the richer countries to smart out of the economic shocks that have been occasioned by the corona virus while poorer countries are likely to resort to foreign debts and foreign aids as economic recovery strategies. The consequences of this will manifest a deepened overdependence by the poor countries on the richer countries of the global system. In the end, the international system is likely to go through another circle of imperialism in which the poor countries will be consigned to deeper marginality and imperialistic manipulative antics. Thus, the nature of international economic relations in the post-corona pandemic is not likely to excite so much of cheering prospects for the poor countries of the global system, if they do not evolve ways of revamping their indigenous economies.

It is possible for most of the stronger nations to strengthen cooperation in the post-corona pandemic era; but there are fears that strained relationships may take sometimes to heal. For instance, the unsavoury diplomatic exchanges between the United States and China concerning the outbreak of the Corona Virus Disease and HIV/AIDS generated tensions between the two global economic giants; and this had deepened the frosty relationship between the two, which 


\section{International Journal of Social Science and Economic Research}

ISSN: $2455-8834$

Volume:05, Issue:12 "December 2020"

may take sometimes to heal. This is certainly going to have a consequence for international relations in the post-corona pandemic era.

\section{Conclusion and Suggestions}

From the foregoing, it is convincing to conclude that the experience of cross-border interactions during the corona virus pandemic illustrates the notion that international relations will always come under the influence of global dynamics. This is based on our findings which show that the corona virus pandemic and its concomitant challenges have had a telling impact on the nature of international relations. The impact cuts across diplomatic relations, trans-border travels and international migrations, cooperation among super powers and international economic relations. Very importantly too, the corona virus has exposed the inadequacies of the global health systems. It is, therefore, suggested that a global synergy in the area of proactive approaches through advances in medical science is required to prevent the reoccurrence of a similar global pandemic. This is because it will be more rewarding to take proactive measures in dealing with issues that affect the global system than coming behind from a reactionary position. Added to that is the need for less developed nations to evolve strategic economic policies that will enhance the growth of their domestic economies for economic independence in a volatile and everchanging world order.

\section{References}

Adegbelu, F. (2006), "Theories of International Relations," in Adegbulu,F. (ed), Topics and Issues in International Relations, Ilishan Remo, Babcock University Press.

Brown, C. (2005), Understanding International Relations (Third Edition, Revised and Updated), Basingstoke, Hampshire, Palgrave MacMillan.

Daulaire, N. (1999), "Globalization and Health," International Roundtable: Rethinking Equity and Health, Jointly Organized by Society for International Development (SID), World Health Organization (WHO) and the Rockefeller Foundation (RF), July 12.

Farmer, P. (2001), "The Major Infectious Diseases in the World: To Treat or Not to Treat," New England Journal of Medicine, 345 (3), pp. 208-210.

Goldstein, J.S. \& Pevehouse, J.C. (2011) International Relations (Ninth Edition), New York, Pearson/Longman.

http:www.who.int/hiv/data/epi_core_dec20.14. Retrieved 10/09/2020. 
International Journal of Social Science and Economic Research

ISSN: 2455-8834

Volume:05, Issue:12 "December 2020"

Kaplan, R.D. (2000) "The Coming Anarchy," in Mearma, P.O. \& Krain, M. (eds), Globalization and the Challenges of a New Century: A Reader, Bloomington, Indiana University Press.

Orngu, C.S. (2007), "Contending Issues in the HIV/AIDS Problematic," Faculty of Arts Journal (FAJ), Vol. 4, pp. 20-22.

Salcedo, A., Yar, S, \& Cherelu, G. (2020), "Corona Virus Restrictions across the Globe," New York Times, May 8.

The Guardian (2014), Ebola Cases in West Africa Could Rise to 20,000, Says WHO," August, 28.

WHO (2020) "Director-General's Opening Remarks at Media Briefing on Covid-19," Geneva, Switzerland, March 11. Accessed on www.who.int. on September 13, 2020.

www.aljazeera.com. Retrieved 10/09/2020.

www.worldmeters.info. Retrieved 10/09/2020. 